\title{
Osmotic Effects of Infusion of THAM
}

\author{
William G. Heird ${ }^{[20]}$, Ralph B. Dell, Trevor Price, and Robert W. Winters \\ Department of Pediatrics, College of Physicians and Surgeons of Columbia University, New York, New York, USA
}

\begin{abstract}
Extract
Changes in plasma osmolality as well as in extracellular fluid (ECF) space following infusion of THAM or $\mathrm{NaHCO}_{3}$ to anesthetized, nephrectomized dogs have been used to compare the osmotic effects of the two agents. Groups of five to six dogs received (per $\mathrm{kg}$ body weight) 10 millimoles THAM (pH 7.3), 10 millimoles THAM (pH 8.5), 5 millimoles $\mathrm{NaHCO}_{3}, 10$ millimoles $\mathrm{NaHCO}_{3}$ or 5 millimoles $\mathrm{NaCl}$, while a control group of five dogs received no infusion. Increases in plasma osmolality and ${ }^{36} \mathrm{Cl}$ space (ECF) were greater following infusion of THAM ( $\mathrm{pH} 7.3$ or $\left.\mathrm{pH} 8.5\right)$ than after infusion of either $\mathrm{NaHCO}_{3}$ or $\mathrm{NaCl}$. Specifically, the osmotic effects of THAM, as judged from increases in osmolality of the body fluids and in ${ }^{36} \mathrm{Cl}$ space, were much greater than those of a 5-millimole dose of $\mathrm{NaHCO}_{3}$, which produced an equivalent rise in plasma bicarbonate, and were even greater than those of an equimolar dose of $\mathrm{NaHCO}_{3}(10$ millimoles $/ \mathrm{kg})$. Furthermore, the increase in concentration of plasma bicarbonate produced by this dose of $\mathrm{NaHCO}_{3}$ was much greater than that produced by THAM. Although theoretical considerations have predicted that the osmotic effects of THAM would be as great or greater than those of $\mathrm{NaHCO}_{3}$, this is the first experimental documentation.
\end{abstract}

\section{Speculation}

The results reported herein provide further evidence for the view that THAM is not superior to $\mathrm{NaHCO}_{3}$ for treatment of clinical acid-base disturbances.

\section{Introduction}

Tris (hydroxymethyl) aminomethane, or THAM, has been advocated as a more effective alkalinizing agent than bicarbonate or lactate for the treatment of clinical states of acidosis, particularly respiratory acidosis. This view is based in part upon the fact that THAM, in contrast to other buffers, can neutralize carbonic acid and thus lower the $\mathrm{CO}_{2}$ tension of such patients [12]. In addition, the facts that THAM is a stronger base than bicarbonate ( $\mathrm{pK}^{\prime} 7.84$ versus 6.10$)$ and that it allegedly enters cells more rapidly than bicarbonate $[8$, 11] have been proffered as further evidence of its superiority. Finally, since THAM contains no sodium, it has been argued that THAM would exert fewer osmotic effects than would the sodium-containing buffers and thus it would be particularly advantageous for use in patients in whom the administration of sodium is undesirable [9].

These points attesting to the superiority of THAM as an in vivo buffer have been challenged on theoretical and experimental grounds. They have been discussed extensively by Bleich and Schwartz [2], and all points except the last have been adequately negated. The purpose of this study was to test the contention that THAM exerts fewer osmotic effects than do sodium-containing buffers and thereby minimizes internal redistribution of total body water (TBW). 


\section{Materials and Methods}

Mongrel dogs weighing 9-12 $\mathrm{kg}$ were anesthetized with sodium pentobarbital. ( $30 \mathrm{mg} / \mathrm{kg}$ body weight), intubated, given succinylcholine (as necessary to maintain paralysis of the respiratory muscles) and ventilated with a variable rate and volume respiratory pump. End tidal $\mathrm{CO}_{2}$ was maintained at a value which maintained $\mathrm{Pa}_{\mathrm{CO}_{2}}$ constant at approximately $40 \mathrm{~mm} \mathrm{Hg}$. Catheters were placed in the femoral artery (for blood sampling and for monitoring of blood pressure) and in the femoral vein (for administration of infusions). Ligatures were placed about the splenic and renal pedicles through a midline abdominal incision in order to prevent changes in blood volume during the experiment and to prevent excretion of isotopes and other infused agents as well as renal acid-base adjustments.

Group I (five dogs) received 10 millimoles $/ \mathrm{kg}$ body weight of a $4 \mathrm{~m}$ solution of THAM titrated with $\mathrm{HCl}$ to $\mathrm{pH} 8.5$, the $\mathrm{pH}$ of the commercial preparation. Highly concentrated solution was used to minimize the water load incident to the infusion. As an osmotic control (i.e., without acid-base effect), Group II (six dogs) received 10 millimoles $/ \mathrm{kg}$ body weight of $4 \mathrm{M}$ THAM titrated with $\mathrm{HCl}$ to $\mathrm{pH} 7.33$ - the mean $\mathrm{pH}$ of the nephrectomized control animals when maintained at a $\mathrm{Pa}_{\mathrm{CO}_{2}}$ of $40 \mathrm{~mm} \mathrm{Hg}$. To compare the osmotic effects of THAM infused at $\mathrm{pH} 8.5$ with an amount of $\mathrm{NaHCO}_{3}$ yielding similar acid-base effects, Group III (six dogs) received 5 millimoles of I M $\mathrm{NaHCO}_{3}$ per kilogram. Group IV (five dogs) received 10 millimoles of $1 \mathrm{M} \mathrm{NaHCO}$ per kilogram in order to compare the effects of equimolar amounts of $\mathrm{NaHCO}_{3}$ and THAM. Group $V$ (five dogs) received 5 millimoles of $4 \mathrm{M} \mathrm{NaCl}$ per kilogram, and thus served as a further osmotic control. Group VI (six dogs) received no infusion. Group VII (six dogs), like Group I, received 10 millimoles $/ \mathrm{kg}$ of $4 \mathrm{M}$ THAM at $\mathrm{pH} 8.5$; in this group, however, ECF volume was estimated from the volume of distribution of ${ }^{14} \mathrm{C}$-inulin rather than ${ }^{36} \mathrm{Cl}$.

Figure 1 shows the results obtained in a single animal in Group $I$ and serves to illustrate the experimental design. Ninety to 120 min before infusion of the osmotic agent to be studied (i.e., THAM, $\mathrm{NaHCO}_{3}$, etc.), tritiated water (THO) and ${ }^{36} \mathrm{CI}$ were injected; 20 min before the osmotic infusion, ${ }^{51} \mathrm{Cr}$-tagged erythrocytes were injected. Control blood samples for the necessary analyses (see below) were obtained just prior to the infusion. The infusion required 10-20 min, the end of which was designated time 0 . Blood samples were obtained at $30,60,90,120,180$, and $300 \mathrm{~min}$ thereafter. Whole blood samples were counted for ${ }^{51} \mathrm{Cr}$, and the concentrations of ${ }^{36} \mathrm{Cl}$ and $\mathrm{THO}$ in plasma were determined [5]. Concentrations of $\mathrm{Na}+$,

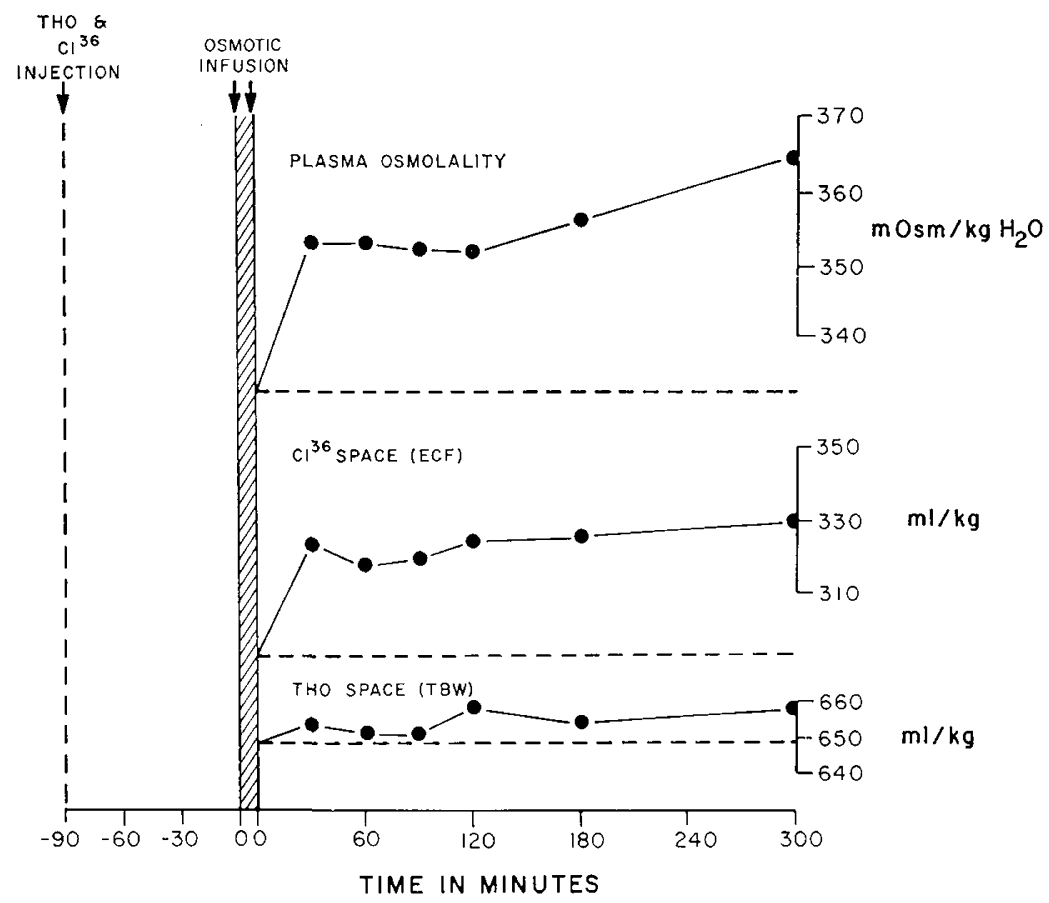

Fig. 1. Experimental design. ECF: extracellular fluid. $T B W$ : total body water. 


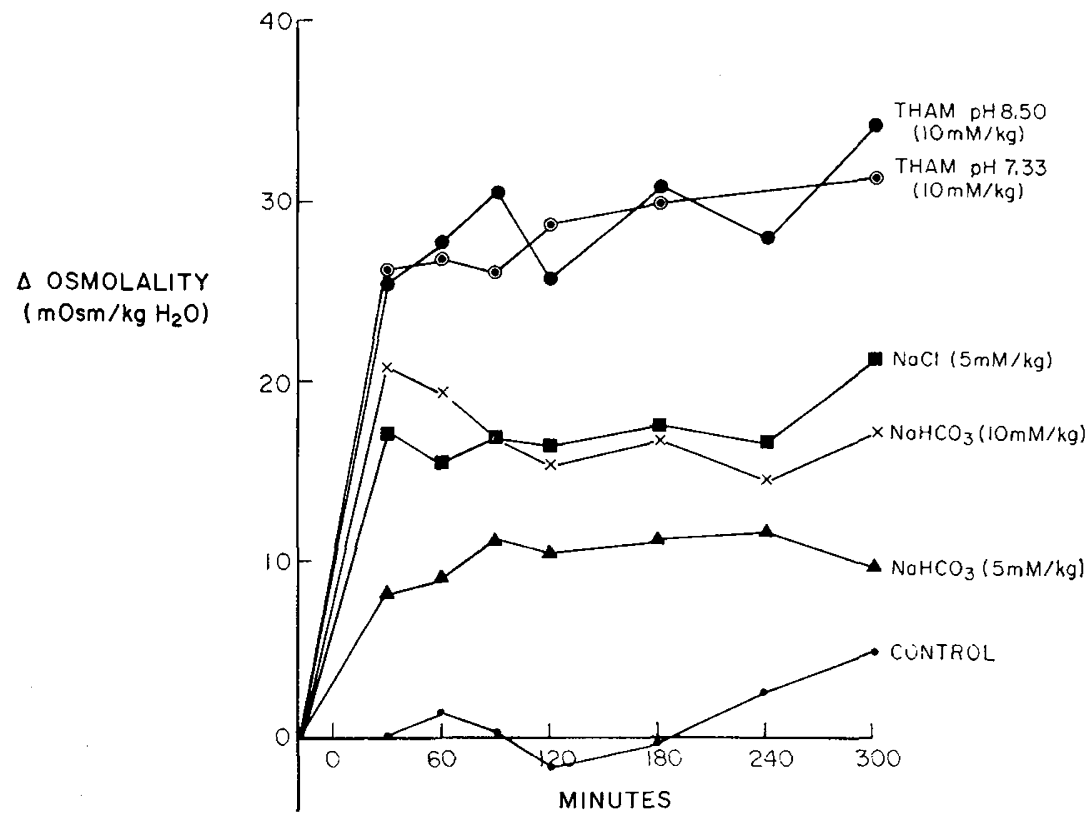

Fig. 2. Increase in osmolality following infusion of $\mathrm{THAM}, \mathrm{NaHCO}_{3}$, or $\mathrm{NaCl}$.

$\mathrm{K}^{+}, \mathrm{Cl}^{-}$, glucose, and urea in plasma as well as blood acid-base status were determined in duplicate for each sample [1, 4]. Plasma osmolality was determined by freezing point depression with an osmometer [16].

Throughout the experiment, small amounts of $0.9 \%$ $\mathrm{NaCl}$ were given to maintain patency of the catheters as well as for administration of succinylcholine; the total volume of the infusions over the entire 5-hr period was never more than $30 \mathrm{ml} / \mathrm{kg}$ body weight.

\section{Results}

Figure 2 depicts the mean increase in plasma osmolality observed in all groups of animals during the experiment (Groups I and VII are combined in this figure). It is obvious that the rise in osmolality was greatest in those animals which received THAM of either pH. A significantly smaller rise in osmolality was observed in the animals which were given 5 millimoles of $\mathrm{NaCl}$ per kilogram body weight or either dose of $\mathrm{NaHCO}_{3}$. Small rises in osmolality occurred in nearly all groups near the end of the experiment; these were attributable in part to the observed increases in concentrations of urea, $\mathrm{Na}^{+}$and $\mathrm{Cl}^{-}$, the latter being incident to the small infusions necessary to maintain catheter patency.

Table I shows the mean changes in TBW and ECF observed in each of the seven groups. The total body water increased slightly $(15-20 \mathrm{ml} / \mathrm{kg})$ in all experiments due to accumulation of the small amounts of fluid used to maintain patency of the catheter and to infuse necessary drugs. In each of the infused groups, ECF volume showed an abrupt increase which was maintained throughout the 5-hr period of study.

In order to estimate the effects of the administered osmotic load upon the increase in ECF volume, ECF volume was calculated as the percentage of TBW at each time period for each dog. The increase in this proportion for each time period was then calculated as a percentage change of the value observed at time 0 . These values for all dogs in each group were averaged so that the final value represents the group mean of $\left(\mathrm{ECF}_{t} / \mathrm{TBW}_{t}\right) /\left(\mathrm{ECF}_{1} / \mathrm{TBW}_{1}\right)$. This calculation is tantamount to estimating the ratio of osmotic load as a proportion of total ECF solute to osmotic load as a proportion of total body solute (see Appendix). The calculated values are depicted in Figure 3 . As would be expected from the changes in plasma osmolality, the increase in ECF volume induced by THAM infused at either $\mathrm{pH} 8.5$ or pH 7.3 (Groups $I$ and $I I$ ) was significantly greater than that induced by any other agent. Animals which received $\mathrm{NaHCO}_{3}$ (Groups $I I I$ and $I V$ ) and those which received $\mathrm{NaCl}$ (Group V) had increases in ECF volume which were significantly larger than those observed in the controls (Group VI).

Table II shows the changes in plasma $\left[\mathrm{HCO}_{3}{ }^{-}\right]$ noted over the course of the experiment in each group. During the first 90-120 min, the increase in plasma $\left[\mathrm{HCO}_{3}^{-}\right]$produced by the infusion of 5 millimoles of 
Table $I$. Volumes of total body water (TBW) and extracellular fluid (ECF) in each group of animals

\begin{tabular}{|c|c|c|c|c|c|c|c|c|c|c|c|c|c|c|}
\hline \multirow[t]{2}{*}{$\begin{array}{c}\text { Time, } \\
\text { min }\end{array}$} & \multicolumn{2}{|c|}{$\begin{array}{c}\text { Group I: } \\
\text { THAM, pH 8.5, } \\
10 \text { millimoles } / \mathrm{kg} \\
\end{array}$} & \multicolumn{2}{|c|}{$\begin{array}{c}\text { Group II: } \\
\text { THAM, pH } 7.3, \\
10 \text { millimoles } / \mathrm{kg}\end{array}$} & \multicolumn{2}{|c|}{$\begin{array}{c}\text { Group III: } \\
\text { NaHCO } \\
5 \text { millimoles } / \mathrm{kg}\end{array}$} & \multicolumn{2}{|c|}{$\begin{array}{c}\text { Group IV: } \\
\text { NaHCOs, } \\
10 \text { millimoles } / \mathrm{kg}\end{array}$} & \multicolumn{2}{|c|}{$\begin{array}{c}\text { Group V: } \\
\text { NaCl, } \\
5 \text { millimoles } / \mathrm{kg}\end{array}$} & \multicolumn{2}{|c|}{$\begin{array}{l}\text { Group VI: } \\
\text { control }\end{array}$} & \multicolumn{2}{|c|}{$\begin{array}{c}\text { Group VII: } \\
\text { THAM, pH 8.5, } \\
10 \text { millimoles } / \mathrm{kg}\end{array}$} \\
\hline & TBW & $\mathrm{ECF}^{2}$ & TBW & $E C F$ & TBW & ECF & TBW & $\mathrm{ECF}$ & TBW & ECF & TBW & $E C F$ & $T B W$ & ECF \\
\hline 0 & 648 & 294 & 638 & 264 & 636 & 266 & 655 & 276 & 592 & 250 & 661 & 282 & 628 & 170 \\
\hline 30 & 654 & 325 & 642 & 301 & 649 & 285 & 660 & 302 & 598 & 265 & 673 & 287 & 631 & 196 \\
\hline 60 & 652 & 319 & 648 & 304 & 649 & 286 & 665 & 302 & 597 & 264 & 672 & 289 & 639 & 192 \\
\hline 90 & 651 & 320 & 646 & 304 & 649 & 284 & 666 & 302 & 597 & 263 & 674 & 293 & & \\
\hline 120 & 659 & 326 & 646 & 299 & 649 & 286 & 672 & 301 & 601 & 270 & 689 & 300 & 644 & 197 \\
\hline 180 & 655 & 323 & 644 & 297 & 653 & 288 & 674 & 302 & 600 & 271 & 680 & 300 & 647 & 203 \\
\hline 240 & & & & & 654 & 293 & 672 & 304 & 601 & 272 & 688 & 305 & 648 & 205 \\
\hline 300 & 659 & 331 & 659 & 315 & 657 & 299 & 676 & 304 & 605 & 276 & 692 & 308 & 644 & 209 \\
\hline
\end{tabular}

${ }_{1} \mathrm{TBW}$ in milliliters per kilogram calculated from tritiated water space; standard deviation of the observations is $56.4 \mathrm{ml} / \mathrm{kg}$. This standard deviation is the pooled standard deviation for each group and is the best estimate of the standard deviation for each value in the table.

${ }^{2} \mathrm{ECF}$ in milliliters per kilogram calculated from ${ }^{36} \mathrm{Cl}$ space except for Group $V I I$ where ECF was calculated from ${ }^{14} \mathrm{C}$-inulin space; standard deviation of the observation is $31.8 \mathrm{ml} / \mathrm{kg}$.

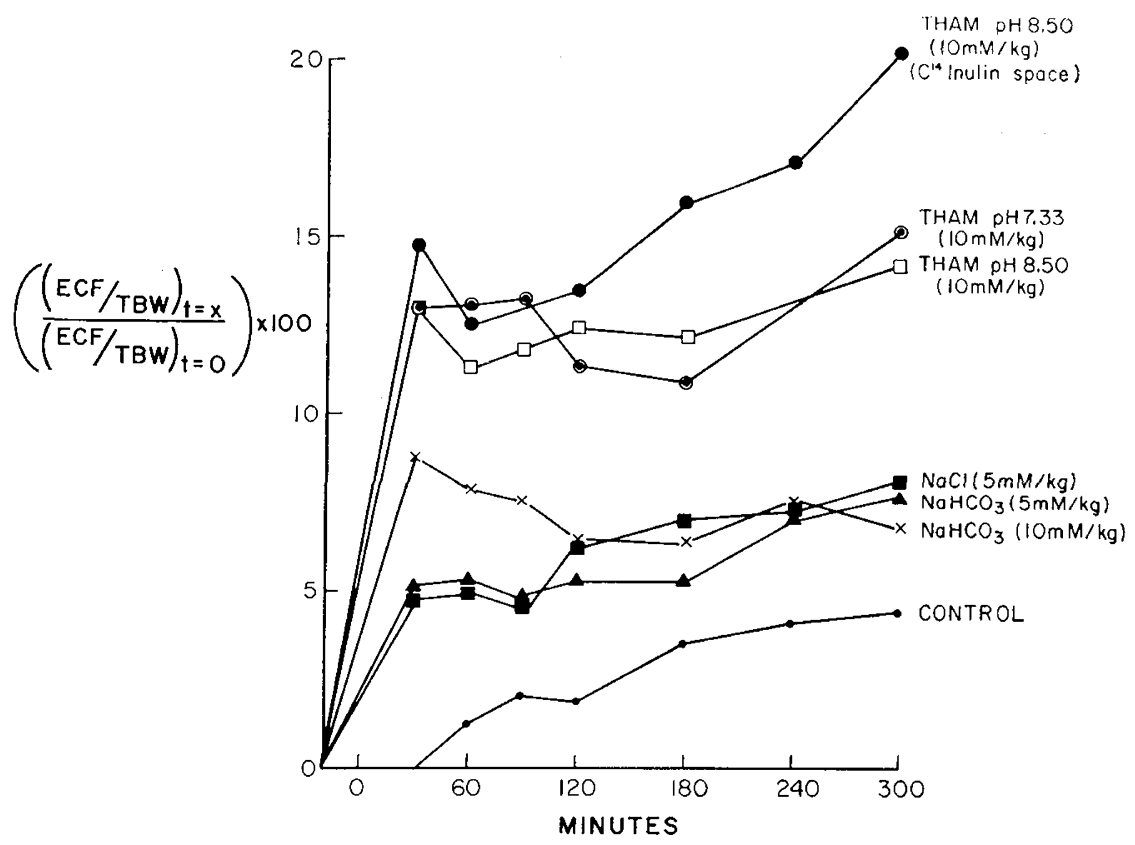

Fig. 3. Percentage increase in ratio of extracellular fluid (ECF) to total body water (TBW) following infusion of $\mathrm{THAM}_{\mathrm{H}} \mathrm{NaHCO}_{3}$, or $\mathrm{NaCl}^{\text {. }}$

$\mathrm{NaHCO}_{3}$ per kilogram body weight (Group III) was nearly as great as that induced by 10 millimoles of THAM at $\mathrm{pH} 8.5$ per kilogram (Group $I$ ) but only about one-half that observed after infusion of 10 millimoles of $\mathrm{NaHCO}_{3}$ per kilogram (Group IV). After 120 min, plasma $\left[\mathrm{HCO}_{3}^{-}\right]$tended to decrease in all groups of animals, which reflected acid accumulation incident to nephrectomy and general deterioration of the preparation. Changes in blood $\mathrm{pH}$ closely reflect those expected from observed changes in plasma $\left[\mathrm{HCO}_{3}{ }^{-}\right]$at a constant $\mathrm{P}_{\mathrm{CO}_{2}}$; these changes, as well as those which occurred in plasma $\left[\mathrm{Na}^{+}\right]$, are presented in Table III.

\section{Discussion}

The major purpose of this study was to determine whether THAM produces smaller increases in osmolality and ECF volume than does a comparable quantity of $\mathrm{NaHCO}_{3}$. The results indicate that THAM causes a greater increase in osmolality of the body fluids as well as a larger percentage increase in ECF volume than does the dose of $\mathrm{NaHCO}_{3}$ which produces an equivalent rise in plasma $\left[\mathrm{HCO}_{3}^{-}\right]$(compare Groups $I$ and $I I I)$. Indeed, the increases in osmolality and ECF volume induced by THAM are even larger than those 
induced by an equimolar amount of $\mathrm{NaHCO}_{3}$ (compare Groups $I$ and $I V$ ); the latter, however, causes a much larger increase in plasma $\left[\mathrm{HCO}_{3}-\right]$.

It is possible, by application of osmometric principles [14], to calculate the apparent osmotic load delivered to each group of animals studied (see Appendix). Table IV compares the calculated osmotic load received by each group with the osmotic load actually administered. It is somewhat difficult to calculate the osmotic load precisely because the osmotic consequences of the acid-base reactions undergone by both

Table II. Variation of plasma bicarbonate concentration with timel

\begin{tabular}{|c|c|c|c|c|c|c|}
\hline Time, $\min$ & $\begin{array}{l}\text { Group } 1: \\
\text { THAM: } \\
\text { pH } 8.5, \\
10 \text { milli- } \\
\text { moles } / \mathrm{kg}\end{array}$ & $\begin{array}{c}\text { Group II: } \\
\text { THAM, } \\
\text { pH 7.3 } \\
10 \text { milli- } \\
\text { moles } / \mathrm{kg}\end{array}$ & $\begin{array}{c}\text { Group III: } \\
\mathrm{NaHCO}_{3}, \\
5 \mathrm{milli}- \\
\mathrm{moles} / \mathrm{kg}\end{array}$ & $\begin{array}{l}\text { Group IV } \\
\mathrm{NaHCO}_{3}, \\
10 \mathrm{milli}^{-} \\
\text {moles/kg }\end{array}$ & $\begin{array}{c}\text { Group V: } \\
\mathrm{NaCl}, \\
5 \mathrm{milli}- \\
\text { moles } / \mathrm{kg}\end{array}$ & $\begin{array}{c}\text { Group VI } \\
\text { control }\end{array}$ \\
\hline 0 & 18.8 & 19.0 & 17.5 & 18.4 & 18.6 & 20.3 \\
\hline 30 & 27.8 & 19.1 & 29.2 & 37.5 & 19.3 & 20.7 \\
\hline 60 & 27.5 & 18.9 & 27.5 & 36.7 & 19.5 & 21.0 \\
\hline 90 & 27.7 & 18.8 & 27.2 & 36.2 & 19.7 & 20.6 \\
\hline 120 & 26.4 & 18.0 & 26.2 & 35.0 & 19.4 & 20.9 \\
\hline 180 & 24.5 & 16.6 & 25.8 & 34.4 & 19.0 & 20.0 \\
\hline 240 & & & 25.0 & 32.4 & 17.7 & 20.3 \\
\hline 300 & 19.1 & 15.7 & 23.3 & 31.7 & 17.4 & 19.3 \\
\hline
\end{tabular}

${ }^{1}$ In milliequivalents per liter. Pooled standard deviation is 2.1 $\mathrm{mEq} /$ liter.
$\mathrm{NaHCO}_{3}$ and THAM must be estimated. Thus, in determining the osmotic load actually delivered, two assumptions were made. First, that $40 \%$ of the infused bicarbonate $\left(\mathrm{NaHCO}_{3}\right)$ reacts with nonbicarbonate buffers to yield the conjugate base forms of the nonbicarbonate buffers (no net osmotic change) and $\mathrm{H}_{2} \mathrm{CO}_{3}$ [13]. The latter is eliminated as $\mathrm{CO}_{2}$ so that only $60 \%$ of the infused bicarbonate remains as an osmotically active particle-e.g., 10 millimoles of infused $\mathrm{NaHCO}_{3}$ would yield 16 milliosmoles, 10 from $\mathrm{Na}^{+}$and 6 from $\mathrm{HCO}_{3}{ }^{-}$. Second, that at $\mathrm{pH} 8.5,18 \%$ of the total amount of THAM is present as the chloride salt and so yields two osmotically active particles. Following infusion of THAM, the mean blood $\mathrm{pH}$ was 7.42 , and at this $\mathrm{pH}$ THAM is $73 \%$ ionized. Consequently, $55 \%$ of the total THAM has reacted with weak acids (HBuf and $\mathrm{H}_{2} \mathrm{CO}_{3}$ ) to yield conjugate bases but only $60 \%$ of these are present as $\mathrm{HCO}_{3}$ - (newly produced osmotic particles). Thus, 10 millimoles of THAM ( $\mathrm{pH} 8.5$ ) after administration yield 10 milliosmoles THAM, 1.8 milliosmoles $\mathrm{Cl}-$ and 3.3 milliosmoles $\mathrm{HCO}_{3}{ }^{-}$, giving a total osmotic load of 15.1 milliosmoles. There is excellent agreement between the administered and the calculated osmotic loads at $60 \mathrm{~min}$, which suggests that no unexpected factors contribute to the rise in osmolality observed after administration of any of the agents studied.

Table III. Variation of blood $\mathrm{pH}$ and concentration of sodium in plasma with time ${ }^{1}$

\begin{tabular}{|c|c|c|c|c|c|c|}
\hline Time, $\min$ & $\begin{array}{c}\text { Group I: } \\
\text { THAM, pH } 8.5, \\
10 \text { millimoles } / \mathrm{kg}\end{array}$ & $\begin{array}{c}\text { Group II: } \\
\text { THAM, pH 7.3, } \\
10 \text { millimoles } / \mathrm{kg}\end{array}$ & $\begin{array}{c}\text { Group III: } \\
\mathrm{NaHCO}_{3,} \\
5 \text { millimoles } / \mathrm{kg}\end{array}$ & $\begin{array}{c}\text { GroupIV: } \\
\mathrm{NaHCO}_{3} \\
10 \text { millimoles } / \mathrm{kg}^{2}\end{array}$ & $\begin{array}{c}\text { Group V: } \\
\text { NaCl, } \\
5 \text { millimoles } / \mathrm{kg}\end{array}$ & $\begin{array}{c}\text { Group VI: } \\
\text { control }\end{array}$ \\
\hline & \multicolumn{6}{|c|}{ Blcod $\mathrm{pH}^{2}$} \\
\hline 0 & 7.298 & 7.307 & 7.283 & 7.290 & 7.305 & 7.319 \\
\hline 30 & 7.426 & 7.272 & 7.449 & 7.600 & 7.305 & 7.316 \\
\hline 60 & 7.425 & 7.271 & 7.444 & 7.599 & 7.320 & 7.328 \\
\hline 90 & 7.407 & 7.276 & 7.444 & 7.608 & 7.325 & 7.329 \\
\hline 120 & 7.424 & 7.273 & 7.434 & 7.602 & 7.326 & 7.336 \\
\hline 180 & 7.426 & 7.266 & 7.426 & 7.584 & 7.326 & 7.345 \\
\hline 240 & & & 7.426 & 7.571 & 7.312 & 7.340 \\
\hline \multirow[t]{2}{*}{300} & 7.363 & 7.204 & 7.399 & 7.572 & 7.298 & 7.335 \\
\hline & \multicolumn{6}{|c|}{ Plasma $\left[\mathrm{Na}^{+}\right]^{3}$} \\
\hline 0 & 152.2 & 149.3 & 156.2 & 150.2 & 153.1 & 149.2 \\
\hline 30 & 144.4 & 136.5 & 162.8 & 164.1 & 163.2 & 147.3 \\
\hline 60 & 141.7 & 137.8 & 162.4 & 164.0 & 162.7 & 147.2 \\
\hline 90 & 145.8 & 138.8 & 162.6 & 164.0 & 162.8 & 147.4 \\
\hline 120 & 145.3 & 139.3 & 163.8 & 162.5 & 162.2 & 147.0 \\
\hline 180 & 146.0 & 139.8 & 162.7 & 162.6 & 160.4 & 145.9 \\
\hline 240 & & & 162.1 & 161.5 & 160.1 & 145.4 \\
\hline 300 & 149.4 & 142.3 & 161.6 & 162.1 & 160.3 & 145.4 \\
\hline
\end{tabular}

1 Average of all values at each time period.

2 Pooled standard deviation is 0.047 .

${ }^{3}$ In milliequivalents per liter. Pooled standard deviation is $5.66 \mathrm{mEq} / \mathrm{liter}$. 
Table IV. Administered and calculated osmotic loads in the treated animals

\begin{tabular}{|c|c|c|c|c|c|}
\hline & $\begin{array}{c}\text { Group I: } \\
\text { THAM, pH } 8.5, \\
10 \text { millimoles } / \mathrm{kg}\end{array}$ & $\begin{array}{c}\text { Group II: } \\
\text { THAM, pH } 7.3, \\
10 \text { millimoles } / \mathrm{kg}\end{array}$ & $\begin{array}{c}\text { Group III: } \\
\mathrm{NaHCO}_{3} \\
5 \text { millimoles } / \mathrm{kg}\end{array}$ & $\begin{array}{c}\text { Group IV: } \\
\text { NaHiCO } \\
10 \text { millimoles } / \mathrm{kg}\end{array}$ & $\begin{array}{c}\text { Groutp V: } \\
\quad \mathrm{NaCl}, \\
5 \text { millimoles } / \mathrm{kg}\end{array}$ \\
\hline Administered osmotic load, milliosmoles $/ \mathrm{kg}^{1}$ & 15.10 & 17.70 & 8.00 & 16.00 & 10.00 \\
\hline Calculated osmotic Ioad, milliosmoles $/ \mathrm{kg}^{2}$ & 17.60 & 17.90 & 9.20 & 16.10 & 10.00 \\
\hline Mean $\triangle \mathrm{BE}, \mathrm{mEq} /$ liter $^{3}$ & 9.5 & & 11.9 & 21.20 & \\
\hline Calculated osmotic load (milliosmoles & 85 & & & & \\
\hline Mean $\triangle \mathrm{BE}$ & 1.80 & & 0.17 & 0.10 & \\
\hline
\end{tabular}

1 Calculated as follows:

(a) Group I (final plasma pH 7.42; 1.51 milliosmoles/millimole infused):

HBuf +0.82 THAM +0.18 THAMCl $\rightarrow 0.73 \mathrm{THAM}^{+}+0.18 \mathrm{Cl}^{-}+0.33 \mathrm{HCO}_{3}^{-}+0.22 \mathrm{Buf}^{-}+0.27 \mathrm{THAM}$

(b) Group II (final plasma $\mathrm{pH} 7.30 ; 1.77$ milliosmoles/millimole infused):

0.23 THAM +0.77 THAMCl $\rightarrow 0.23 \mathrm{THAM}^{\mathrm{T}}+0.77 \mathrm{THAM}^{+}+0.77 \mathrm{Cl}^{-}$

(c) Groups III and IV (1.6 milliosmoles/millimole infused):

$\mathrm{NaHCO}_{3}+\mathrm{HBuf} \rightarrow \mathrm{Na}^{+}+0.6 \mathrm{HCO}_{3}^{-}+0.4 \mathrm{Buf}^{-}$

(d) Group $V$ (2 milliosmoles/millimole infused):

$\mathrm{NaCl} \rightarrow \mathrm{Na}^{+}+\mathrm{Cl}^{-}$

${ }^{2}$ Calculated as follows (see Appendix) $:$ load $=\operatorname{TBW}_{1} \Delta[\mathrm{Osm}]+\mathrm{L}_{\mathrm{HH}_{2} \mathrm{O}}[\mathrm{Osm}]$, where TBW is the total body water, [Osm] the osmolal-

${ }^{3} \Delta \mathrm{BE}=$ base excess at 60 min minus control base excess. ity, and $\mathrm{L}_{\mathrm{H}_{2} \mathrm{O}}$ the water given with the infused solute.

The ratio of the osmotic load delivered to the available base delivered can be calculated for both THAM and $\mathrm{NaHCO}_{3}$ from the data in Table IV and the mean change observed in blood base excess. After $60 \mathrm{~min}$, the mean blood base excess had risen by $9.5 \mathrm{mEq} /$ liter in the animals given THAM at $\mathrm{pH} 8.5$ (Group I), whereas it had increased by $11.9 \mathrm{mEq} /$ liter in those which received 5 millimoles of $\mathrm{NaHCO}_{3}$ per kilogram body weight (Group III) and by $21.2 \mathrm{mEq} /$ liter in those which received 10 millimoles $\mathrm{NaHCO}_{3} / \mathrm{kg}$ (Group $I V)$. The ratio of calculated osmotic load delivered to the mean increase in blood base excess for each group demonstrates clearly that for each milliequivalent rise in blood base excess, THAM delivers more than twice the osmotic load delivered by $\mathrm{NaHCO}_{3}$.

It can be argued that, since THAM is excreted rapidly by the kidney, such an osmotic effect would not be seen in the intact patient. However, in a dog with intact, well perfused kidneys only $30-35 \%$ of an administered dose of THAM is excreted in $1 \mathrm{hr}$ [10]. Furthermore, the percentage of THAM excreted by patients who usually require THAM-i.e., patients with severe acid-base disturbances and concomitant reduction in glomerular filtration rate and urine flowis likely to be less than that observed in normal dogs. The osmotic consequences after infusion of THAM or $\mathrm{NaHCO}_{3}$ to dogs with intact kidneys are currently being investigated and will be the subject of a subsequent report.

It can also be argued that the rise in osmolality induced by THAM would have no effects upon internal distribution of body water if THAM, like urea, readily penetrated cells. On the other hand, if THAM were confined entirely to the ECF or entered cells only slowly, an increase in ECF volume would result. This could be of considerable importance, particularly in infants with respiratory distress syndrome or other such conditions associated with a compromised circulation. The observed data on changes in body fluid compartments (see Table I and Fig. 3) show that, although TBW remained relatively constant after THAM infusion, a sharp increase in ECF volume did, indeed, occur and that this increase was sustained throughout the 5-hr observation period.

The fact that ECF volume remains elevated after THAM administration has at least three explanations, and these are not necessarily mutually exclusive: $(a)$ it is an artifact of equating the ${ }^{36} \mathrm{Cl}$ space with the ECF volume; (b) THAM enters cells by exchanging with some intracellular substance; $(c)$ THAM enters cells very slowly.

The first explanation can be eliminated by the data from dogs of Group VII (Table I). These animals received 10 millimoles per $\mathrm{kg}$ body weight of THAM at pH 8.5, and the ECF volume was estimated by the volume of distribution of ${ }^{14} \mathrm{G}$-inulin. The results (Fig. 3) indicate that, even when a radically different ECF marker is employed, ECF volume increases following THAM administration and remains elevated throughout the course of the experiment. Thus, the increases 
in ${ }^{36} \mathrm{Cl}$ space observed in the other groups are more likely due to ECF volume expansion and not to an artifact of equating ${ }^{36} \mathrm{Cl}$ space with $\mathrm{ECF}$ volume.

There is some evidence for the second and third explanations. If THAM entered cells by exchanging with some intracellular substance, it should be possible to detect accumulation of this substance in the osmolar composition of the ECF. Therefore, calculated ECF osmoles were compared with measured ECF osmoles. Calculated osmoles at each time were determined by multiplying the osmotic concentrations of the measured contributors to extracellular osmolality $\left(\mathrm{Na}^{+}\right.$, $\mathrm{K}+, \mathrm{Cl}^{-}, \mathrm{HCO}_{3}^{-}$, urea, and glucose) by the respective ECF volume [15] and then summing the individual contributions at each time. The control or preinfusion calculated osmoles were then subtracted from the calculated osmoles at each postinfusion time, thereby giving the total increase in calculated ECF osmoles. These increases in total calculated ECF osmoles, expressed in milliosmoles per kilogram of body weight, are plotted in Figure 4. Also plotted are the increases in measured ECF osmoles at each time; these were calculated by multiplying the measured osmolality (determined by freezing depression) by the respective ECF volumes.

In the control animals (bottom panel, Fig. 4), there was a small but increasing discrepancy between calculated and measured osmoles. This suggests an accumulation, in nephrectomized animals, of a substance(s) other than those mentioned above. On the other hand, in both groups which received $\mathrm{NaHCO}_{3}$ there was only slight (if any) discrepancy between the calculated and the measured osmoles, implying not only that most of the increase in osmolality was due to administered $\mathrm{NaHCO}_{3}$ but also that maintenance of normal or elevated plasma bicarbonate concentration may reduce or eliminate the accumulation of the unknown substance(s) observed in the control group. In the dogs which received THAM, a discrepancy between the measured and calculated osmoles was also seen; it appeared early in the experiment and remained constant throughout. This discrepancy, which should represent the osmoles contributed by the THAM remaining in the ECF, was about 7 milliosmoles $/ \mathrm{kg}$ body weightapproximately $30 \%$ less than the total THAM administered.

Studies of the kinetics of THAM distribution do not agree about the amount of THAM expected to remain in the ECF at various times following its administration. According to Holmdahl and Nahas [7], the discrepancy between calculated and measured extracellu-

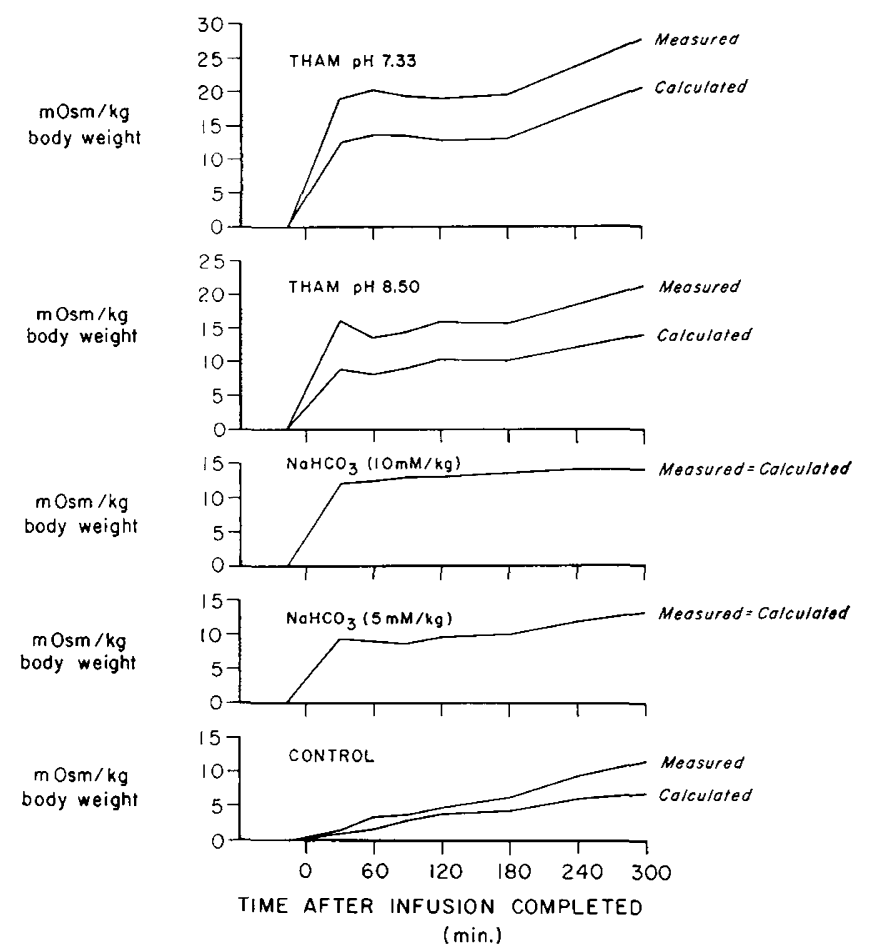

Fig. 4. Measured and calculated osmoles following administration of $\mathrm{NaHCO}_{3}$ or THAM.

lar osmoles that we have noted approximates the amount of THAM that would be expected to remain in the ECF up to $60 \mathrm{~min}$ after its administration. On the other hand, the discrepancy is somewhat greater than the amount that would be predicted from the studies of Robin et al. [11], but it is somewhat less than our unpublished kinetic data would suggest.

The fact that the discrepancy between calculated and measured osmoles in this study is less than the amount of THAM administered, together with the findings of the previously cited studies of the kinetics of THAM distribution [7, 11], indicates that THAM does leave the EGF, although at a rate which appears to vary from study to study. The constancy of the discrepancy noted between calculated and measured extracellular osmoles in this study-if this discrepancy truly represents the osmoles contributed by the THAM which remains in the ECF-suggests that little, if any, THAM enters the nonextracellular space except during the first $30 \mathrm{~min}$ after administration. This interpretation, however, is not consistent with previously reported studies $[7,11]$ or with our unpublished studies of the kinetics of THAM distribution. Alternatively, the constancy of the discrepancy between calculated and measured osmoles could be explained by an exchange between THAM and an intra- 
cellular solute other than $\mathrm{Na}^{+}, \mathrm{K}^{+}, \mathrm{Cl}^{-}, \mathrm{HCO}_{3}^{-}$, or glucose so that the total ECF osmolality remains constant. Such an exchange need not be energy-linked or, for that matter, even related to the disappearance of THAM from the ECF. Indeed, accumulation in the ECF of the same substance(s) noted in control animals would easily explain the discrepancy.

It is obvious that the data reported here do not allow a precise interpretation of the discrepancy between calculated and measured ECF osmolality observed after THAM administration. However, animals in Groups $I$ and $I I$ were given THAM labeled with ${ }^{14} \mathrm{C}$ which permitted determination of the apparent volume of distribution of ${ }^{14} \mathrm{C}$-THAM. This only slowly approached the measured total body water; in fact, preliminary examination of the kinetics of THAM distribution indicates that it takes approximately 12-18 hr for THAM to equilibrate throughout the measured TBW - a far longer time than has previously been reported [7]. Whether there is an exchange process (related or unrelated) between THAM and another intracellular solute remains to be proven. Thus, it appears that THAM does enter cells but at a relatively slow rate. A thorough study of the kinetics of THAM distribution throughout TBW will be the subject of a forthcoming publication.

These experiments, then, indicate that THAM does not produce fewer osmotic effects than does $\mathrm{NaHCO}_{3}$. In fact, for equivalent acid-base changes, THAM causes a greater increase in plasma osmolality than does $\mathrm{NaHCO}_{3}$. Furthermore, since THAM penetrates cells relatively slowly, these osmotic effects are accompanied by a considerable increase in ECF volume which persists for some hours in nephrectomized dogs. Thus, these results provide further evidence for the view that THAM is not superior to $\mathrm{NaHCO}_{3}$ for treatment of clinical acid-base disturbances.

\section{Summary}

The osmotic effects of THAM, as judged by increases induced in plasma osmolality and EGF $\left({ }^{36} \mathrm{Cl}\right)$ space of nephrectomized dogs, are somewhat greater than those of an equimolar amount of $\mathrm{NaHCO}_{3}$. Furthermore, the increases in plasma $\left[\mathrm{HCO}_{3}{ }^{-}\right]$and in blood $\mathrm{pH}$ following $\mathrm{NaHCO}_{3}$ administration are considerably greater than those induced by equimolar amounts of THAM, which indicates that, for equivalent acid-base changes, the osmotic effects of THAM far exceed those of $\mathrm{NaHCO}_{3}$.

\section{Appendix}

Let: $\mathrm{TBW}=$ total body water in $\mathrm{ml} / \mathrm{kg}$

$\mathrm{ECF}=$ extracellular fluid volume in $\mathrm{ml} / \mathrm{kg}$

$\mathrm{L}_{\mathrm{osm}}=$ osmotic load in milliosmoles $/ \mathrm{kg}$

$\mathrm{L}_{\mathrm{H}_{2} \mathrm{O}}=$ water load in $\mathrm{ml} / \mathrm{kg}$

osm $=$ osmolality in milliosmoles $/ \mathrm{kg} \mathrm{H} \mathrm{H}_{2} \mathrm{O}$

TBS = total body solute in milliosmoles $/ \mathrm{kg}$

ECFS $=$ extracellular fluid solute in milliosmoles $/ \mathrm{kg}$

Subscripts 1 and 2 refer to times before and after infusion, respectively.

If an osmotic load is confined to the ECF, then:

$$
\mathrm{ECFS}_{1}+\mathrm{L}_{\mathrm{osm}}=\mathrm{ECFS}_{2}
$$

or

$$
\mathrm{ECF}_{1} \cdot \mathrm{osm}_{1}+\mathrm{L}_{\mathrm{osm}}=\mathrm{ECF}_{2} \cdot \mathrm{osm}_{2}
$$

Similarly, for the total body water:

$$
\mathrm{TBW}_{1} \cdot \mathrm{osm}_{1}+\mathrm{L}_{\mathrm{osm}}=\mathrm{TBW}_{2} \cdot \mathrm{osm}_{2}
$$

Eliminating osm $\mathrm{os}_{2}$ between the two equations yields:

$$
\frac{\mathrm{ECF}_{2}}{\mathrm{TBW}_{2}}=\frac{\mathrm{ECF}_{1} \cdot \mathrm{osm}_{1}+\mathrm{L}_{\mathrm{osm}}}{\mathrm{TBW}_{1} \cdot \mathrm{osm}_{1}+\mathrm{L}_{\mathrm{osm}}}=\frac{\mathrm{EGFS}_{1}+\mathrm{L}_{\mathrm{osm}}}{\mathrm{TBS}_{1}+\mathrm{L}_{\mathrm{osm}}}
$$

At osmotic equilibrium the ratio of the volumes of $\mathrm{ECF}$ and TBW is given by the ratio of the solute in the ECF to the total body solute, or:

$$
\frac{\mathrm{EGF}_{1}}{\mathrm{TBW}_{1}}=\frac{\mathrm{EGFS}_{1}}{\mathrm{TBS}_{1}}
$$

Therefore:

$$
\begin{aligned}
& \left(\frac{\mathrm{ECF}_{2}}{\mathrm{TBW}_{2}}\right) /\left(\frac{\mathrm{EGF}_{1}}{\mathrm{TBW}_{1}}\right)=\left(\frac{\mathrm{EGFS}_{1}+\mathrm{L}_{\mathrm{osm}}}{\mathrm{TBS}_{1} \mathrm{~L}_{\mathrm{osm}}}\right) \\
& \quad /\left(\frac{\mathrm{ECFS}_{1}}{\mathrm{TBS}_{1}}\right)=\left(1+\frac{\mathrm{L}_{\text {osm }}}{\mathrm{EGFS}_{1}}\right) /\left(1+\frac{\mathrm{L}_{\mathrm{osm}}}{\mathrm{TBS}_{1}}\right)
\end{aligned}
$$

From equation (3) osmotic load may be calculated as:

$$
\begin{aligned}
\mathrm{L}_{\mathrm{osm}} & =\mathrm{TBW}_{2} \cdot \mathrm{osm}_{2}-\mathrm{TBW}_{1} \cdot \mathrm{osm}_{1} \\
& =\left(\mathrm{TBW}_{1}+\mathrm{L}_{\mathrm{H}_{2} \mathrm{O}}\right)_{\mathrm{osm}}-\mathrm{TBW}_{1} \cdot \mathrm{osm} \\
& =\mathrm{TBW}_{1} \cdot \Delta \mathrm{osm}+\mathrm{L}_{\mathrm{H}_{2} \mathrm{O}} \cdot \mathrm{osm}_{2}
\end{aligned}
$$

\section{References and Notes}

1. Asch, M. J., Dell, R. B., Williams, G. S., Cohen, M., ANd Winters, R. W.: Time course for development of respixatory acidosis. J. Lab. Clin. Med., 73: 610 (1969).

2. BleIch, H. L., AND SchwarTZ, W. B.: Tris Buffer (THAM): an appraisal of its physiological effects and clinical usefulness. New Engl. J. Med., 274: 782 (1966). 
3. Bolam, T. R.: The Donnan Equilibrium. (Bell, London, 1932).

4. DeLL, R. B., AND Winters, R. W.: Lactate gradients in the kidney of the dog. Amer. J. Physiol., 213: 301 (1967).

5. Dell, R. B., LeE, C. E., AND Winters, R. W.: Influence of body composition on the in vivo response to hypercapnia. Pediat. Res., 5: 523 (1971).

6. Harned, H. S., And OWen, B. B.: The Physical Chemistry of Electrolytic Solutions, Ed. 3. (Reinhold Publishing Corp., New York, 1963).

7. Holmdahl, M. H., and Nahas, G. G.: Volume of distribution of $\mathrm{C}^{14}$-labelled Tris (hydroxymethyl) aminomethane. Amer. J. Physiol., 202: 1011 (1962).

8. Ligou, J. C., AND Nahas, G. G.: Comparative effects of acidosis induced by acid infusion and carbon dioxide accumulation. Amer. J. Physiol., 198: 1201 (1960).

9. NAHAS, G. G.: Use of buffers in management of respiratory failure. Ann. N. Y. Acad. Sci., 121: 871 (1965).

10. Nahas, G. G., and Reveilland, R. J.: Elimination du 2 amino-2-hydroxy-methyl-1,3-propanediol par le rein. C. R. Acad. Sci. (Paris), 253: 721 (196I).

11. Robin, E. D., Wilson, R. J., ANd BromberG, P. A.: Intracellular acid-base relations and intracellular buffers. Ann. N. Y. Acad. Sci., 92: 539 (1961).

12. Sieker, H. O., Merwarth, C. R., and Saltzman, H. A.: The use of 2-amino-2-hydroxymethyl-1,3-propanediol in severe carbon dioxide intoxication. Ann. N. Y. Acad. Sci., 92: 783 (1961).
13. Winters, R. W., AND Dell, R. B.: Regulation of acid-base equilibrium. In: W. S. Yamamoto and J. R. Brobeck: Physiological Controls and Regulations, Chapt. 10, p. 181 (W. B. Saunders Co., Philadelphia, 1965).

14. Wolf, A. V., ANd MCDowell, M. E.: Apparent and osmotic volumes of distribution of sodium, chloride, sulfate and urea. Amer. J. Physiol., 176: 207 (1954).

15. Appropriate plasma water corrections, Donnan factors [3], and osmotic coefficients [6] were used in these calculations.

I6. $3 \mathrm{R} \mathrm{Hi}$-Precision research osmometer, Advanced Instruments, Inc., Newton Highlands, Mass.

17. This work was presented to the New York Heart Association Scientific Session on Research, April 28, 1970.

18. Dr. William C. Heird was the recipient of a Senior Fellowship from the New York Heart Association. Dr. RaIph B. Dell was the recipient of Public Health Service Research Career Development Award no. 5 KO33 GM-19779. Dr. Robert W. Winters is the recipient of a Career Scientist Award from the Health Research Council of the City of New York under Contract no. I-309.

19. This work was supported by Public Health Service Research Grant no. HD-03993 from the National Institute of Child Health and Human Development.

20. Requests for reprints should be addressed to: William C. HeIrd, M.D., Department of Pediatrics, College of Physicians and Surgeons of Columbia University, 630 West 168th Street, New York, N. Y. 10032 (USA).

21. Accepted for publication December 7, 1971. 